\title{
Phytoprotection
}

\section{Sensitivity distribution of Venturia inaequalis to fenarimol in Québec apple orchards}

\section{O. Carisse et J.R. Pelletier}

Volume 75, numéro 1, 1994

URI : https://id.erudit.org/iderudit/706050ar

DOI : https://doi.org/10.7202/706050ar

Aller au sommaire du numéro

Éditeur(s)

Société de protection des plantes du Québec (SPPQ)l

ISSN

0031-9511 (imprimé)

1710-1603 (numérique)

Découvrir la revue

Citer cet article

Carisse, O. \& Pelletier, J. (1994). Sensitivity distribution of Venturia inaequalis to fenarimol in Québec apple orchards. Phytoprotection, 75(1), 35-43.

https://doi.org/10.7202/706050ar
Résumé de l'article

Cette étude a été faite dans le but d'établir le seuil de sensibilité du Venturia inaequalis au fenarimol, un inhibiteur de la biosynthèse de l'ergostérol. Au cours de la saison 1988, des isolats du V. inaequalis ont été prélevés dans 26 vergers commerciaux du Québec pour un total de 576 isolats monoconidiens. La sensibilité au fenarimol a été établie par des tests d'inhibition de la croissance radiale du mycélium. Les valeurs de $\mathrm{ED}_{50}$ obtenues pour les 26 vergers ont varié de 0,024 à $5,212 \mu \mathrm{g} \mathrm{mL}^{-1}$ pour une moyenne de $0,156 \mu \mathrm{g} \mathrm{mL}^{-1}$. Une réduction de sensibilité, exprimée en valeur de $\mathrm{ED}_{50}$, a été observée dans trois vergers, soit pour $4,51 \%$ des isolats testés. Les isolats sensibles avaient un $\mathrm{ED}_{50}$ moyen de $0,079 \mu \mathrm{g} \mathrm{mL}^{-1}$, et les isolats de sensibilité réduite démontraient un $\mathrm{ED}_{50}$ de $1,714\left(\mu \mathrm{gL}^{-1}\right.$, ce qui représente un facteur de résistance de 22. Quatre populations ont été identifiées en fonction de la distribution de fréquence des valeurs de $\mathrm{ED}_{50}$ 


\title{
Sensitivity distribution of Venturia inaequalis to fenarimol in Québec apple orchards
}

\author{
Odile Carisse $^{1,2}$ and Jean R. Pelletier ${ }^{1}$
}

Received 1993-04-23; accepted 1994-02-04

This study was initiated to quantify the baseline sensitivity of apple scab (Venturia inaequalis) to fenarimol, an ergosterol synthesis-inhibiting fungicide. In 1988, 576 monoconidial isolates of Venturia inaequalis were collected from 26 commercial orchards throughout Québec. Sensitivity to fenarimol was assessed by radial growth inhibition assay. The $\mathrm{ED}_{50}$ values for the 26 orchards ranged from 0.024 to $5.212 \mu \mathrm{g} \mathrm{mL}^{-1}$ with a mean $\mathrm{ED}_{50}$ of $0.156 \mu \mathrm{g} \mathrm{mL}^{-1}$. Reduced sensitivity, expressed as $E D_{50}$, was found in three orchards for an overall frequency of $4.51 \%$ of isolates. Sensitive isolates had a mean $E_{50}$ of $0.079 \mu \mathrm{g}$ $\mathrm{mL}^{-1}$, whereas isolates with reduced sensitivity had a mean $\mathrm{ED}_{50}$ of $1.714 \mu \mathrm{g}$ $\mathrm{mL}^{-1}$, yielding a resistance factor of about 22. Four populations were identified based on the frequency distribution of $E_{50}$ values.

Carisse, O. et J.R. Pelletier. 1994. Répartition de la tolérance du Venturia inaequalis au fénarimol dans les vergers du Québec. PHYTOPROTECTION 75: 35-43.

Cette étude a été faite dans le but d'établir le seuil de sensibilité du Venturia inaequalis au fénarimol, un inhibiteur de la biosynthèse de l'ergostérol. Au cours de la saison 1988, des isolats du $V$. inaequalis ont été prélevés dans 26 vergers commerciaux du Québec pour un total de 576 isolats monoconidiens. La sensibilité au fénarimol a été établie par des tests d'inhibition de la croissance radiale du mycélium. Les valeurs de $\mathrm{ED}_{50}$ obtenues pour les 26 vergers ont varié de 0,024 à $5,212 \mu \mathrm{g} \mathrm{mL}^{-1}$ pour une moyenne de $0,156 \mu \mathrm{g} \mathrm{mL}^{-1}$. Une réduction de sensibilité, exprimée en valeur de $\mathrm{ED}_{50^{\prime}}$ a été observée dans trois vergers, soit pour $4,51 \%$ des isolats testés. Les isolats sensibles avaient un $E D_{50}$ moyen de $0,079 \mu \mathrm{g} \mathrm{mL}^{-1}$, et les isolats de sensibilité réduite démontraient un $E D_{50}$ de $1,714 \mu \mathrm{g} \mathrm{mL}^{-1}$, ce qui représente un facteur de résistance de 22 . Quatre populations ont été identifiées en fonction de la distribution de fréquence des valeurs de $\mathrm{ED}_{50}$.

\section{INTRODUCTION}

Fenarimol (2,4'-dichlorophenyl-alphapyrimidin-5-ylbenzhydryl alcohol) belongs to the sterol demethylation inhibiting (DMI) class of fungicides. These fungicides are used to control several

1. Research Station, Agriculture Canada, 430 Gouin Blvd., Saint-Jean-surRichelieu, Québec, Canada J3B 3E6

2. Author to whom correspondence should be addressed plant diseases including apple scab, caused by Venturia inaequalis (Cke.) Wint. (Szkolnik 1981). The DMI fungicides give the opportunity to control apple scab more effectively in response to actual infection periods. They can inhibit both primary and secondary infections at a later stage and with lower rates than conventional protective fungicides. They are generally more effective under high inoculum pressure (Biggs and Warner 1987), and are interesting because of their prolonged postinfection activity (Szkolnik1981). DMI fungicides are especially 
suited for use in integrated pest management programs (O'Leary et al. 1987).

Despite these advantages, there are concerns about the possible development of resistance to these products. Although the DMI fungicides are considered to be at low risk for resistance, naturally occurring strains of $V$. inaequalis with reduced sensitivities have been reported (Stanis and Jones 1985; Thind et al. 1986). Resistance of $V$. inaequalis strains to bitertanol ( $ß-\left(\left[1,1^{\prime}-\right.\right.$ biphenyl $]-4 y$ loxy)- $\alpha$ (1,1-demethylethyl)-1H-1,2,4-triazole-1ethanol) and other DMI fungicides, and a reduction in disease control $6 \mathrm{yr}$ after the introduction of DMI fungicides, has been observed in Nova Scotia, Canada (Hildebrand et al. 1988). In Israel, no strains with reduced sensitivity to DMI were detected in apple orchards, although DMI fungicides have been used for almost 10 yr and control failures have been observed (Shabi et al. 1990). In the few cases where reduced sensitivity has been observed, it proceeded slowly and was difficult to detect or forecast (Scheinpflug 1988). Thus, it is important to monitor the resistance to DMI and to determine the baseline sensitivity before their routine use. The baseline sensitivity should be determined based on a large number of isolates from a wide range of regions and orchards since the response of the different populations of $V$. inaequalis to DMI is variable (Braun and McRae 1992; Köller et al. 1991a; Smith et al. 1991). Although the DMI fungicides belong to different chemical families, they all share a common mode of action on $V$. inaequalis and may lead to cross-resistance in populations of $V$. inaequalis (Köller 1988). Monitoring of resistance for one DMI fungicide may provide relevant information for the others. It also was suggested that fenarimol be used for routine resistance monitoring (Stanis and Jones 1985).

DMI fungicides were registered for use on apple in Québec in 1992. The present evaluation of resistance to a DMI fungicide will indicate the natural range of sensitivity and will improve monitoring for potential development of resistance.

The aim of this study was to measure the baseline sensitivity to fenarimol and describe the sensitivity distribution of many isolates of $V$. inaequalis from all major apple production regions in Québec before the intensive use of DMI fungicides.

\section{MATERIALS AND METHODS}

\section{Propagation of Venturia inaequalis}

Naturally infected apple leaves with distinct sporulating lesions were collected in late summer and fall of 1988 from 26 commercial orchards. The lesions were sprayed with distilled water, placed on a wet filter paper and enclosed in a plastic bag at $15^{\circ} \mathrm{C}$ for one night to favour sporulation. Each leaf was then streaked across a water agar plate (4\% agar) containing $50 \mu \mathrm{g} \mathrm{mL}^{-1}$ of tetracycline and incubated for $24 \mathrm{~h}$ at $15^{\circ} \mathrm{C}$. Single germinated conidia were then removed from the agar under a dissecting microscope and transferred to a Petri dish containing malt agar and $50 \mu \mathrm{g} \mathrm{mL}^{-1}$ of tetracycline. A total of 576 isolates from the 26 orchards were obtained and used for the sensitivity tests. Isolates were stored at $1-2^{\circ} \mathrm{C}$ under mineral oil in culture tubes. Before the sensitivity tests, the isolates were inoculated on petri dishes containing malt agar and incubated for $3-4 \mathrm{wk}$ at $20^{\circ} \mathrm{C}$. The sensitivity tests were carried out within a maximum of 2 mo after the isolation of $V$. inaequalis so that effect of cold storage on isolate vigor or sensitivity was reduced to the minimum (Köller et al. 1991b).

\section{Sampling sites}

The 26 orchards were located in all apple production areas of Québec. None of the orchards had been treated with DMI fungicides prior to the sensitivity tests. However, all orchards had been treated with either protectant or systemic fungicides according to a 7-10 dinterval schedule for several years. Figure 1 illustrates the geographical location of the 26 orchards.

\section{Sensitivity tests}

Fenarimol (technical grade, lot 104ND8) was obtained from Eli Lilly Canada (Elanco Products Company, Indianapolis, IN, USA).

The sensitivity of the monoconidial isolates to fenarimol was determined as follows: three to four different monoco- 
nidial isolates were tested per 9-cm-diam plate for the $\mathbf{5 7 6}$ monoconidial isolates and the assay was repeated three times. Agar plugs $(0.15 \mathrm{~cm}$ diam) were cut from each monoconidial isolate and transferred to plates containing $20 \mathrm{~mL}$ of PDA (potato dextrose agar) with either no fenarimol or with fenarimol at concentrations of $0.2,0.6,1.0,2.2,2.6,3.0,3.4,3.8,4.2,4.6$, or $5.0 \mu \mathrm{g} \mathrm{mL}^{-1}$ for a first series of tests, and with fenarimol at concentrations of $0.005,0.015,0.025,0.035,0.045,0.060$, 0.080 , or $0.100 \mu \mathrm{g} \mathrm{mL}^{-1}$ for a second and third series of tests. The fenarimol was dissolved in ethanol before mixing with PDA previously cooled to $60^{\circ} \mathrm{C}$. Ethanol was added in the controls unamended with fenarimol. The inoculated plates were incubated at $20^{\circ} \mathrm{C}$ for $4-6 \mathrm{wk}$.
The diameter of the agar plug was substracted from the diameter of the colony to obtain the colony diameter increase. The mean diameter of the colony was expressed as the proportion of the mean diameter for the untreated control (mean diameter on fenarimolamended medium/mean diameter on unamended medium). The sensitivity was expressed in $\mu \mathrm{g} \mathrm{mL}^{-1}$ of fenarimol causing $50 \%$ inhibition $\left(E_{50}\right)$ calculated using probit analysis (Finney 1971). The mean diameter of the colonies on fenarimol-amended medium for all isolates were compared with the mean diameter of the control. A value equal or greater than the control would have indicated a possible decay in active ingredient added to the agar. This verification

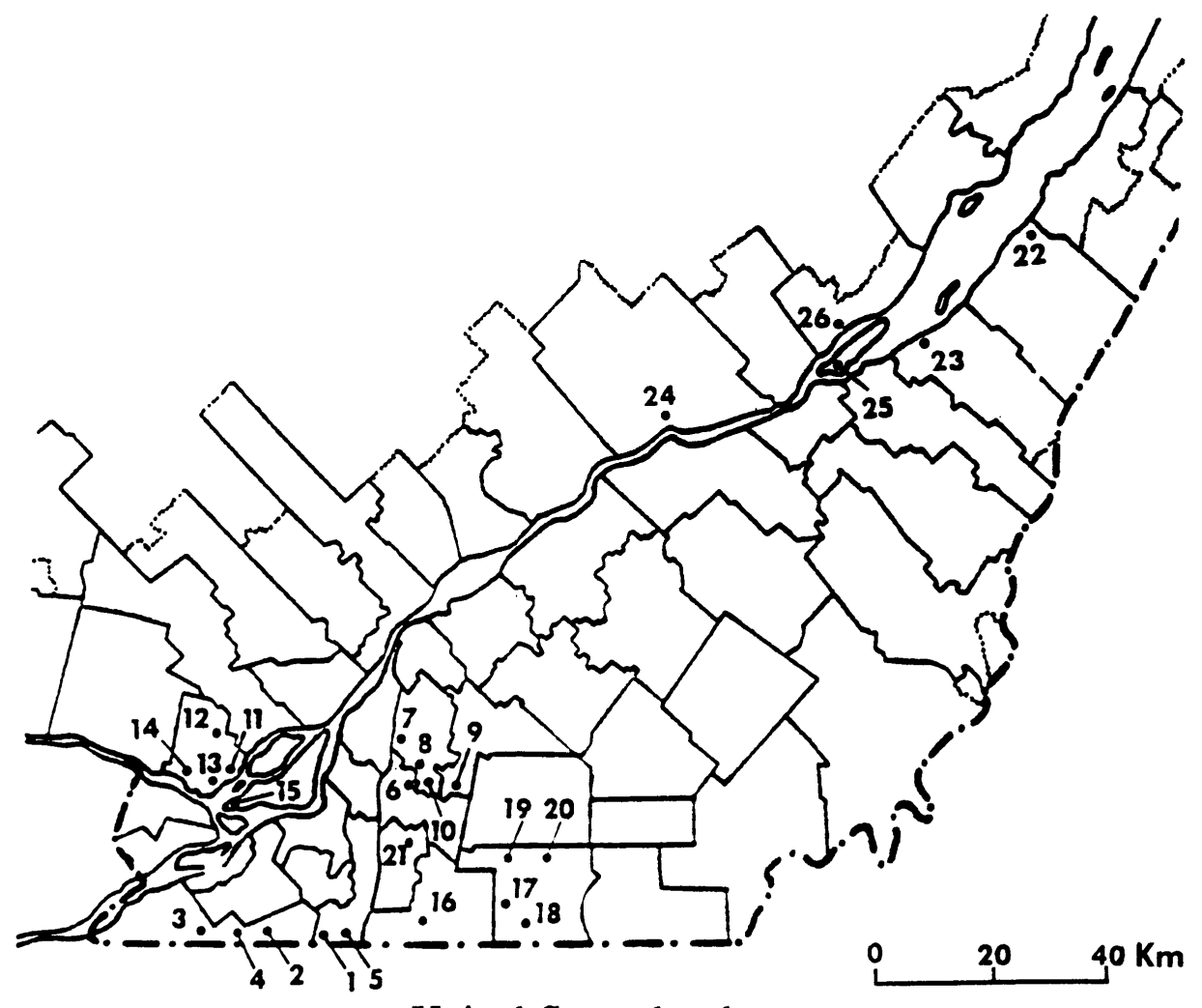

\section{United States border}

Figure 1. Location of the 26 orchards from which the isolates of Venturia inaequalis were collected. Orchard 1 was located in Havelock, 2 and 4 in Franklin, 3 in Rockburn, 5 in Hemmingford, 6 in Saint-Grégoire, 7 and 8 in Rougemont, 9 in Saint-Paul, 10 in Saint-Hilaire, 11 and 12 in Saint-Joseph, 13 in Pointe-Calumet, 14 in Oka, 15 in Sainte-Anne-de-Bellevue, 16 in SaintArmand, 17 to 20 in Frelighsburg, 21 in Saint-Alexandre, 22 in Saint-Roch-des-Aulnaies, 23 in Saint-Ignace, 24 in Deschambault, 25 on île d'Orléans, and 26 in Saint-Joachim. 
was required because, to evaluate sensitivity of $V$. inaequalis based on mycelial growth, it is necessary to incubate the agar plates containing the fungicide for several weeks before the diameter of the colony can be accurately measured. The fungicide tested is not necessarily stable over this incubation period, which may affect the results.

\section{Data analysis}

Frequency distributions of log-transformed $E D_{50}$ values determined for individual orchard populations were analyzed using the univariate procedure (SAS Institute 1988). Normality was tested using the Shapiro-Wilk test when sample size was 50 or less; otherwise the Kolmogorov $D$ test was used. The means of the logtransformed $\mathrm{ED}_{50}$ values of each orchard were compared with the Waller-Duncan K-ratio $T$ test to locate differences among $\mathrm{ED}_{50}$ values calculated for the 26 orchards, and to determine whether orchard populations could be grouped according to their level of sensitivity to fenarimol. The homogeneity of variance among $\mathrm{ED}_{50}$ values for the different orchards was tested using the Bartlett test (Neter and Wasserman 1974).

\section{RESULTS}

The sensitivity of $V$. inaequalis to fungicide fenarimol was quantified based on radial growth inhibition assay. Growth rates on unamended and fenarimolamended media were constant, indicating that nutritional depletion was not a significant factor.

The mean population sensitivity to fenarimol expressed as $E_{50}$ for the 576 isolates was $0.156 \mu \mathrm{g} \mathrm{mL}^{-1}$ with a resistance factor (highest $\mathrm{ED}_{50}$ /lowest $\mathrm{ED}_{50}$ ) of 22 within the population. However, based on the mean of the most frequent $E_{50}$ values obtained, the baseline sensitivity of $V$. inaequalis in Québec to fenarimol is $0.14 \mu \mathrm{g} \mathrm{mL}^{-1}$ (Fig. 2).

Differences in sensitivity to fenarimol were observed among isolates from the 26 orchards and among isolates within the same orchard. The combined mean $\mathrm{ED}_{50}$ values in the 26 orchards ranged from 0.072 to $0.328 \mu \mathrm{g} \mathrm{mL} \mathrm{mL}^{-1}$ (Table 1). Reduced sensitivity, expressed as $\mathrm{ED}_{50}$ was found in isolates from orchards 1,4 , and 9, with a mean $\mathrm{ED}_{50}$ of $0.328,0.243$, and $0.215 \mu \mathrm{g} \mathrm{mL}^{-1}$, respectively. The mean $\mathrm{ED}_{50}$ values in 13 orchards $(6,7,8,11,14$,

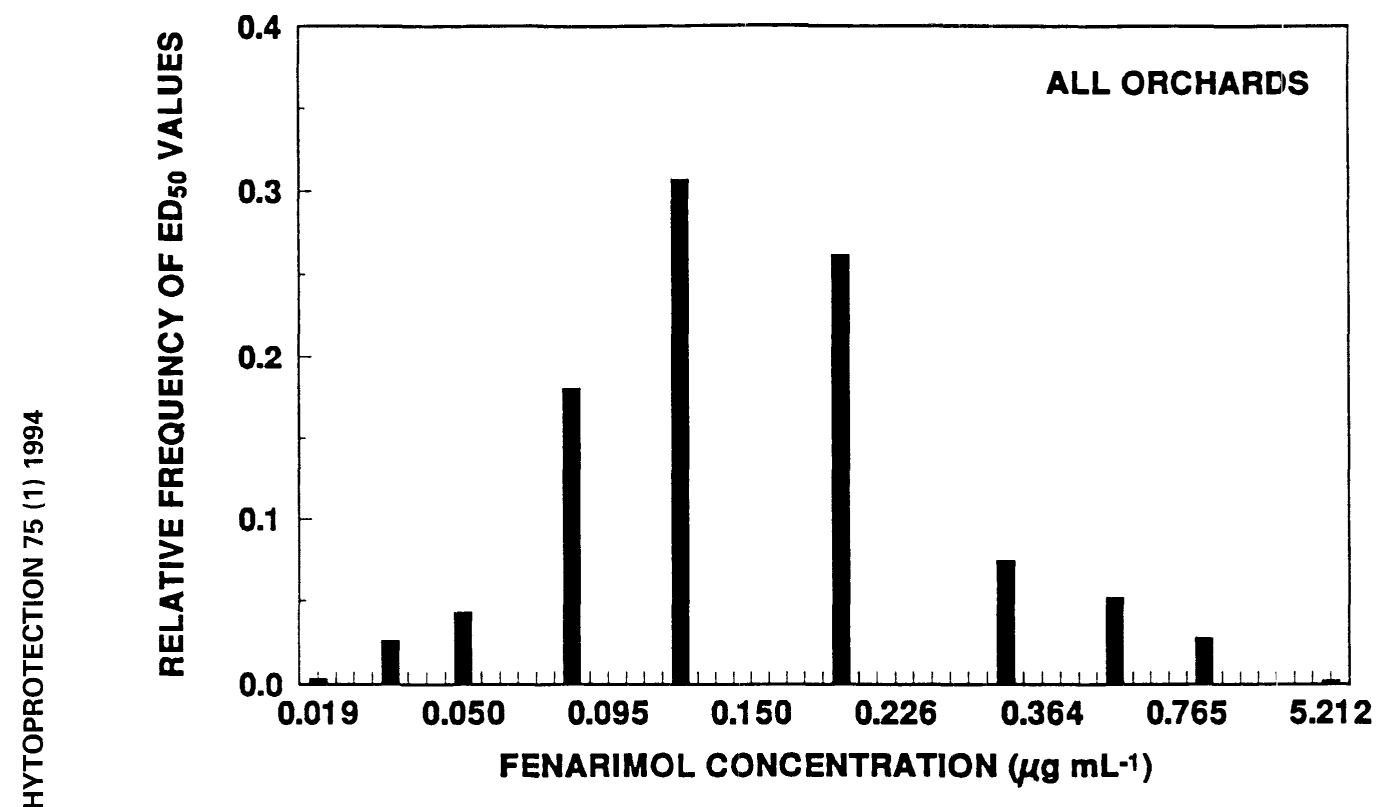

Figure 2. Frequency distribution of $E D_{50}$ values to fenarimol of Venturia inaequalis sampled from 26 apple orchards in Québec. 
Table 1. Sensitivity distribution and baseline sensitivity of Venturia inaequalis to fenarimol

\begin{tabular}{|c|c|c|c|}
\hline \multirow{2}{*}{$\begin{array}{l}\text { Orchard } \\
\text { number }^{\mathrm{a}}\end{array}$} & \multicolumn{2}{|c|}{$E D_{50}\left(\mu \mathrm{g} \mathrm{mL^{-1 }}\right)^{b}$} & \multirow{2}{*}{$\begin{array}{c}\text { Number of } \\
\text { isolates }\end{array}$} \\
\hline & Range & Mean $^{c}$ & \\
\hline 1 & $0.071-5.212$ & 0.328 & 112 \\
\hline 2 & $0.093-0.297$ & 0.149 & 4 \\
\hline 3 & $0.010-0.249$ & 0.159 & 7 \\
\hline 4 & $0.080-1.341$ & 0.243 & 47 \\
\hline 5 & $0.136-0.246$ & 0.177 & 7 \\
\hline 6 & $0.049-0.180$ & 0.091 & 5 \\
\hline 7 & $0.033-0.242$ & 0.072 & 23 \\
\hline 8 & $0.089-0.115$ & 0.103 & 3 \\
\hline 9 & $0.091-1.330$ & 0.215 & 19 \\
\hline 10 & $0.061-0.591$ & 0.157 & 30 \\
\hline 11 & $0.088-0.209$ & 0.120 & 15 \\
\hline 12 & $0.089-0.173$ & 0.136 & 8 \\
\hline 13 & $0.091-0.209$ & 0.149 & 11 \\
\hline 14 & $0.036-0.234$ & 0.091 & 17 \\
\hline 15 & $0.070-0.328$ & 0.138 & 27 \\
\hline 16 & $0.109-0.234$ & 0.167 & 5 \\
\hline 17 & $0.036-0.486$ & 0.156 & 25 \\
\hline 18 & $0.087-0.249$ & 0.159 & 13 \\
\hline 19 & $0.051-0.239$ & 0.122 & 20 \\
\hline 20 & $0.029-0.303$ & 0.106 & 25 \\
\hline 21 & $0.055-0.264$ & 0.101 & 16 \\
\hline 22 & $0.037-0.282$ & 0.118 & 18 \\
\hline 23 & $0.024-0.209$ & 0.111 & 13 \\
\hline 24 & $0.068-0.275$ & 0.109 & 13 \\
\hline 25 & $0.039-0.252$ & 0.103 & 25 \\
\hline 26 & $0.024-0.321$ & 0.108 & 68 \\
\hline All & $0.024-5.212$ & 0.156 & 576 \\
\hline
\end{tabular}

a The location of the orchards is given in Figure 1.

b $E D_{50}$ values were calculated based on mycelial growth inhibition tests.

c Mean $E D_{50}$ for all isolates from the same orchard.

19-26) were less than $0.122 \mu \mathrm{g} \mathrm{mL}-1$, indicating that these isolates were sensitive to fenarimol. The isolates from the remaining 10 orchards had an intermediate sensitivity with mean $\mathrm{ED}_{50}$ values

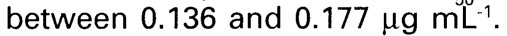

Frequency distribution of the $\mathrm{ED}_{50}$ values (Fig. 3) was log normal for the combined orchard populations according to the Kolmogorov $D$ test $(P \leq 0.01)$, and individually for orchards $1,4,7,9,23$, and 24 according to the Shapiro-Wilk test and the Kolmogorov $D$ test, depending on the sample size $(P \leq 0.05)$. When the means of the log-transformed $\mathrm{ED}_{50}$ values for each orchard were compared, significant differences $(P \leq 0.01)$, were found between orchards with isolates of reduced sensitivity $\left(E D_{50} \geq 0.215\right)$ and orchards with isolates of high sensitivity only. However, significantly different groups of orchard populations could not be detected at the $0.1 \%$ level. The variance among $\mathrm{ED}_{50}$ values for the 26 orchards was not homogeneous when analyzed at the $1 \%$ level. Consequently, univariate analysis and homogeneity of variance test were used to determine which populations could be grouped together. There was homogeneity of variance among $\mathrm{ED}_{50}$ values for four 
populations $(A, B, C$, and $D)$ when analyzed at the $1 \%$ confidence level. $\mathrm{ED}_{50}$ values and the resistance factor for each population are given in Table 2. The most tolerant isolates were found in orchards 1,4 , and 9 , and population D showed the highest level of tolerance (Fig. 3). The order of sensitivity for the four populations was, in increasing order: population $C, B, A$, and D (Table 2).

\section{DISCUSSION}

The population of $V$. inaequalis studied here was slightly more sensitive to fenarimol than what is reported in the literature for wild-type populations (Braun and McRae 1992; Köller et al. 1991a; Stanis and Jones 1985), but not for populations originating from orchards for which reduced disease control was observed (Hildebrand et al. 1988). The mean $\mathrm{ED}_{50}$ obtained for the 576 isolates tested was $0.156 \mu \mathrm{g} \mathrm{mL}^{-1}$, but the sensitivity varied strongly among the different isolates and orchards. The baseline sensitivity of 0.14 $\mu \mathrm{g} \mathrm{mL} \mathrm{m}^{-1}$, derived from this study, is in accordance with those reported by Smith et al. (1991) for the United States, and similar values were obtained by Fiaccadori et al. (1987) and Thind et al. (1986) for the Netherlands and France, respectively. Only 4.51 and $0.6 \%$ of the isolates had an $E D_{50}$ greater or equal to the discriminatory concentration proposed by Stanis and Jones (1985) of 1.0 and 1.5 $\mu \mathrm{g} \mathrm{mL}-1$, respectively. Only one isolate had an $\mathrm{ED}_{50}$ greater than $3.0 \mu \mathrm{g} \mathrm{mL}^{-1}$ concentration at which only resistant isolates can grow (Köller et al. 1991a; Stanis and Jones 1985). All the isolates with reduced sensitivity were found in orchards 1, 4, and 9 located in southern Québec, respectively in Havelock, Franklin and Saint-Paul. These three orchards did not seem to have any common feature that could explain their high level of tolerance to fenarimol, except orchards 1 and 4 that are located in the southwerstern part of Québec near the United States border, where DMI fungicides were in use to manage apple scab. It is thus possible that populations of $V$. inaequalis that have been exposed to DMI fungicides were mixed with wild-type populations in this region.

It was not possible to construct one single frequency distribution of $E D_{50}$ for all the orchard populations that represented all types of distribution. However, the different frequency distributions could be grouped in four distributions representing all orchard populations studied.

The fungicide evaluated in this study is not currently in commercial use on apple in Québec, unlike myclobutanil ( $\alpha$-butyl$\alpha$-(4-chlorophenyl)-1H-1,2,4-triazole-1propanenitrile) which has been recently registered and used by growers for the first time in 1992. The occurrence of cross-

Table 2. Sensitivity distribution of four populations of Venturia inaequalis to fenarimol

\begin{tabular}{|c|c|c|c|c|}
\hline \multirow[b]{2}{*}{ Population } & \multirow{2}{*}{$\begin{array}{l}\text { Orchard } \\
\text { number }^{a}\end{array}$} & \multicolumn{2}{|c|}{$\begin{array}{c}E D_{50}^{b} \\
\left(\mu \mathrm{gL}^{-1}\right)\end{array}$} & \multirow{2}{*}{$\begin{array}{c}\text { Resistance } \\
\text { factor }{ }^{c}\end{array}$} \\
\hline & & Range & Mean & \\
\hline A & $\begin{array}{l}3,5,11,12 \\
13,16\end{array}$ & $0.088-0.249$ & 0.144 & 3 \\
\hline B & $\begin{array}{l}8,14,15 \\
18-21,24-26\end{array}$ & $0.024-0.328$ & 0.112 & 14. \\
\hline $\mathrm{C}$ & $\begin{array}{l}2,4,7,10 \\
17,22,23\end{array}$ & $0.024-1.341$ & 0.148 & 23 \\
\hline$D$ & 1,9 & $0.071-5.212$ & 0.309 & 73 \\
\hline
\end{tabular}

a The location of the orchards is given in Figure 1.

b $\mathrm{ED}_{50}$ values were calculated based on mycelial growth inhibition tests.

c The resistance factor was calculated as highest $E D_{50} /$ lowest $E D_{50}$. 

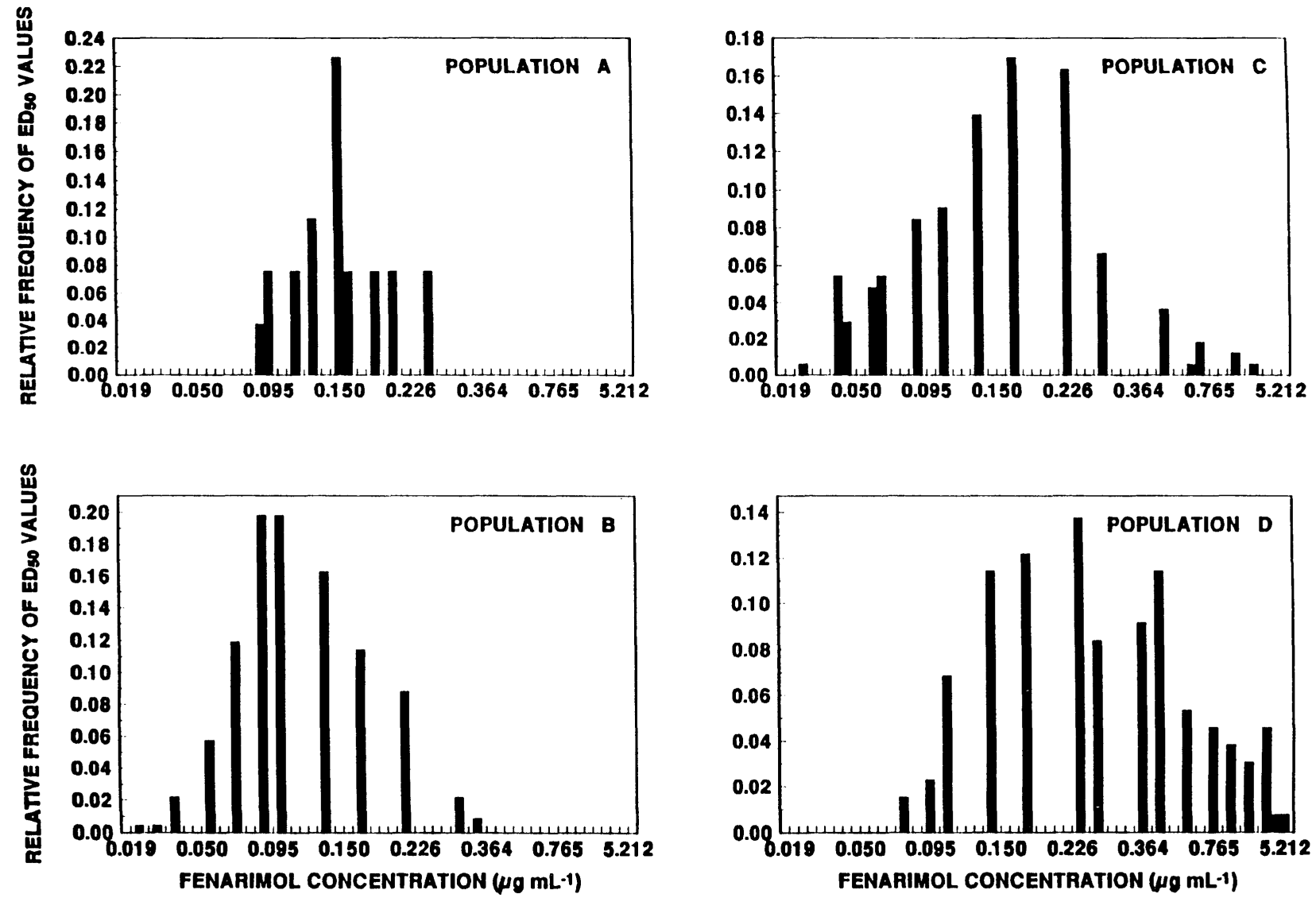

Figure 3. Frequency distribution of $\mathrm{ED}_{50}$ values to fenarimol of Venturia inaequalis for four populations. The distribution was based on homogeneity of variance of $\mathrm{ED}_{50}$ values. The orchard number in each population is given in Table 2 and the location of the orchards in Figure 1. 
resistance has been demonstrated for these two fungicides and other DMI fungicides (Thind et al. 1986). Shabi et al. (1990) observed that the isolates collected from orchards in Israel with reduced sensitivity to fenarimol also exhibited reduced sensitivity to pyrifenox $\left(2^{\prime}, 4^{\prime}\right.$ dichloro-2-(3-pyrydyl) acetophenone O-methyloxime), bitertanol, flusilazol (1[[bis(4-fluorophenyl)methylsilyl]methyl]$1 \mathrm{H}-1,2,4$-triazole) and myclobutanil. It is likely that the less sensitive isolates to fenarimol obtained from Québec orchards also have reduced sensitivity to other DMI fungicides, including myclobutanil.

From this study, we cannot conclude that $V$. inaequalis strains from Québec orchards are less sensitive to fenarimol than other populations, even though isolates with reduced sensitivity were found. However, because reduced sensitivity is controlled by a single gene (Stanis and Jones 1985) there is a strong potential for development of resistance following intensive use of DMI fungicides.

The detection of less sensitive isolates of $V$. inaequalis is a warning that potential problems might arise in practice following intensive use of DMI fungicides. Because myclobutanil, the only registered DMI fungicide for use on apple in Québec, is mostly used in a preventive manner, using more or less the same schedule as for protectants, it is essential to develop and implement a strategy to avoid the selection of resistant strains in the $V$. inaequalis population. Such a strategy may include practices such as reserving the DMI fungicides for the greatest scab danger, especially during the periods of high ascospore discharges and heavy apple tree growth. An alternative strategy might be to delay the first treatment until $5 \%$ of the ascospores are discharged (Gadoury and MacHardy 1986) and to combine DMI fungicides with conventional protectant fungicides to improve their protective action and spectrum of activity. The number of treatments with DMI fungicides can be reduced if they are used in conjunction with a predictive system (Ellis et al. 1984). Such strategies should be adopted in order to reduce the selection pressure for less sensitive strains of $V$. inaequalis and to prolong the effective life of DMI fungicides for as long as pos- sible in the arsenal of scab-management compounds.

\section{REFERENCES}

Biggs, A.R., and J. Warner. 1987. Control of primary and secondary apple scab infections with sterol-inhibiting fungicides. Can. J. Plant Pathol. 9: 41-48.

Braun, P.G., and K.B. McRae. 1992. Composition of a population of $V$. inaequalis resistant to myclobutanil. Can J. Plant Pathol. 14: 215-220.

Ellis, M.A., L.V. Madden, and L.L. Wilson. 1984. Evaluation of an electronic apple scab predictor for scheduling fungicides with curative activity. Plant Dis. 68: 1055-1057.

Fiaccadori, R., A.J. Gielink, and J. Dekker. 1987. Sensitivity to inhibitors of sterol biosynthesis in isolates of Venturia inaequalis from Italian and Dutch orchards. Neth. J. Plant Pathol. 93: 285-287.

Finney, D.J. 1971. Probit analysis. Cambridge University Press, $3^{\text {rd }}$ edition. 333 pp.

Gadoury, D.M., and W.E. MacHardy. 1986. Forecasting ascospore dose of V'enturia inaequalis in commercial orchards. Phytopathology 76: 112-118.

Hildebrand, P.D., C.L. Lockhart, R.J. Newbery, and R.G. Ross. 1988. Resistance of Venturia inaequalis to bitertanol and other demethylation-inhibiting fungicides. Can. J. Plant Pathol. 10: 311-316.

Köller, W. 1988. Sterol demethylation inhibitors: Mechanism of action and resistance. Pages 79-88 in C.J. Delp (ed.), Fungicide resistance in North America. Am. Phytopathol. Soc., St. Paul, MN.

Köller, W., D.M. Parker, and K.L. Reynolds. 1991a. Baseline sensitivities of Venturia inaequalis to sterol demethylation inhibitors. Plant Dis. 75: 726-728.

Köller, W., F.D. Smith, and K.L. Reynolds. 1991b. Phenotypic instability of flusilazole sensitivity in Venturia inaequalis. Plant Pathol. 40: 608-677.

Neter, J., and W. Wasserman. 1974. Applied linear statistical models. Richard D. Irwin Inc., Homewood, IL. 842 pp.

O'Leary, A.L., A.L. Jones, and G.R. Ehret. 1987. Application rates and spray interval for apple scab control with flusilazole and pyrifenox. Plant Dis. 71: 623-626.

SAS Institute Inc. 1988. SAS/STAT User's guide: Release 6.03. SAS Institute Inc., Cary, NC. 1029 pp.

Scheinpflug, H. 1988. Resistance management strategies for using DMI fungicides. Pages 93-94 in C.J. Delp (ed.), Fungicide resistance in North America. Am. Phytopathol. Soc., St. Paul, MN. 
Shabi, E., T. Katan, and A.L. Jones. 1990. Forecasting, detection and evaluation of resistance to ergosterol biosynthesis-inhibiting fungicides in pathogens of apple scab and pear scab. Binational Agricultural Research and Development fund USA-Israel. Final report Project no. 1-750-84. $15 \mathrm{pp}$.

Smith, F.D., D.M. Parker, and W. Köller. 1991. Sensitivity distribution of Venturia inaequalis to sterol demethylation inhibitor flusilazole: baseline sensitivity and implications for resistance monitoring. Phytopathology 81: 392-396.
Stanis, V.F., and A.L. Jones. 1985. Reduced sensitivity to sterol inhibiting fungicides in field isolates of Venturia inaequalis. Phytopathology 75: 1098-1101.

Szkolnik, M. 1981. Physical modes of action of sterol-inhibiting fungicides against apple diseases. Plant Dis. 65: 981-985.

Thind, T., J.M. Olivier, and M. Clerjeau. 1986. Tavelure du pommier: mise en évidence d'une résistance aux fongicides inhibiteurs de la biosynthèse de l'ergostérol. Phytoma 381: 13-16. 